
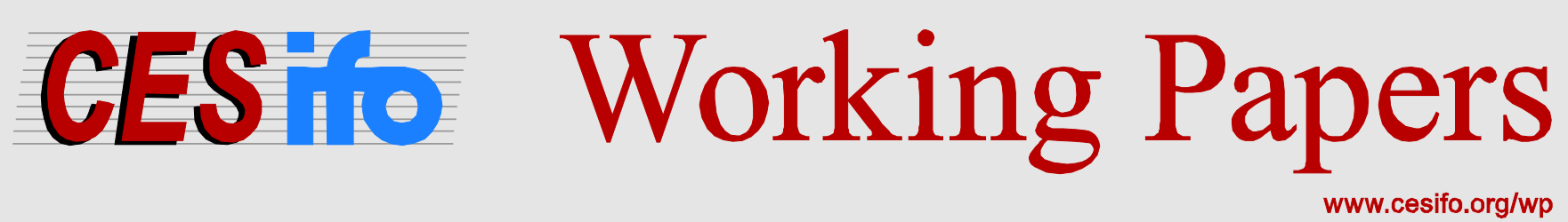

\title{
Curbing Corporate Debt Bias: Do Limitations to Interest Deductibility Work?
}

\author{
Ruud de Mooij \\ Shafik Hebous
}

CESIFO WORKING PAPER NO. 6312

CATEgORY 1: Public FinANCE

JANUARY 2017

An electronic version of the paper may be downloaded

- from the SSRN website:

- from the RePEc website:

- from the CESifo website: WWW.SSRN.com

Www.RePEc.org www.CESifo-group.org/wp 


\title{
Curbing Corporate Debt Bias: Do Limitations to Interest Deductibility Work?
}

\begin{abstract}
Tax provisions favoring corporate debt over equity finance (“debt bias”) are widely recognized as a risk to financial stability. This paper explores whether and how thin-capitalization rules, which restrict interest deductibility beyond a certain amount, affect corporate debt ratios and mitigate financial stability risk. We find that rules targeted at related party borrowing (the majority of today's rules) have no significant impact on debt bias - which relates to third-party borrowing. Also, these rules have no effect on broader indicators of firm financial distress. Rules applying to all debt, in contrast, turn out to be effective: the presence of such a rule reduces the debt-asset ratio in an average company by 5 percentage points; and they reduce the probability for a firm to be in financial distress by 5 percent. Debt ratios are found to be more responsive to thin capitalization rules in industries characterized by a high share of tangible assets.
\end{abstract}

JEL-Codes: G320, H250.

Keywords: corporate tax, capital structure, debt bias, thin capitalization rule.

Ruud de Mooij

International Monetary Fund

Washington DC / USA

rdemooij@imf.org

\author{
Shafik Hebous \\ International Monetary Fund \\ Washington DC / USA \\ shebous@imf.org
}

January 2017

This paper builds on IMF (2016a). We are grateful for research assistance from Tarun Narashimhan and comments from Michael Keen and seminar participants at the IMF. Errors and views are ours alone. The views expressed here are those of the authors and do not necessarily represent the views of the IMF, its Executive Board, or IMF management. 


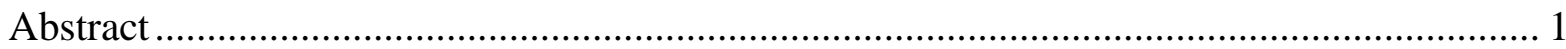

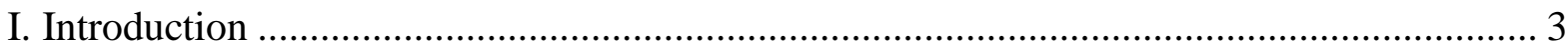

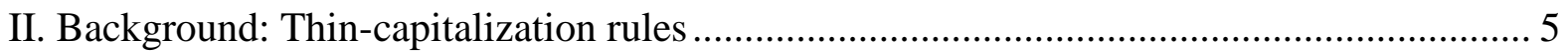

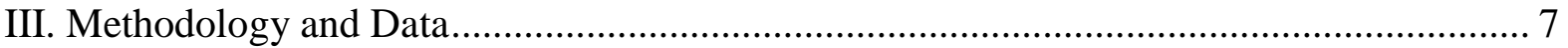

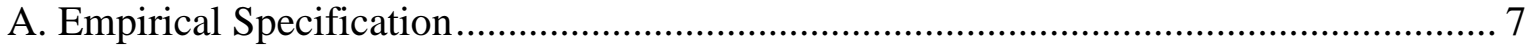

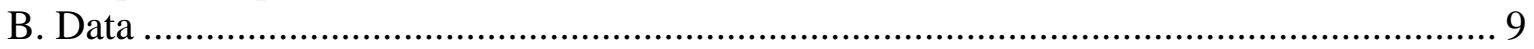

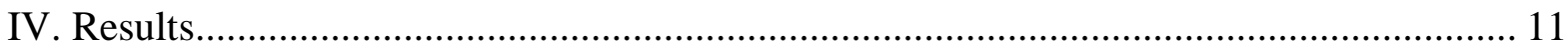

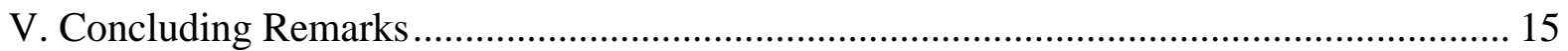

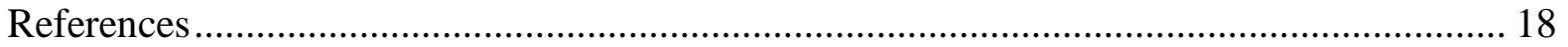

Tables

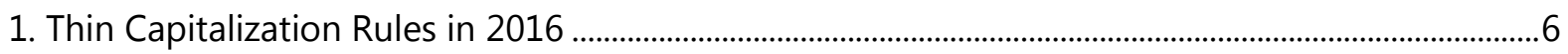

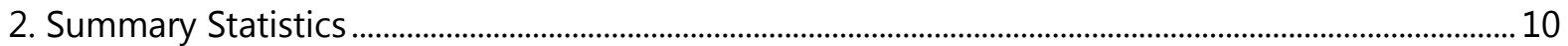

3. Thin Capitalization Rules and Corporate Debt Ratio .......................................................................... 12

4. Thin Capitalization Rules and Tangibility: A Difference-in-Difference Specification......................... 13

5. Thin Capitalization Rules and Corporate Stability................................................................................ 15

6. TCRs, Tangibility, and Corporate Stability—A Diff-in-Diff Specification .............................................. 17

Figure

1. Binned Scatter Plots of Debt Ratios, Z-Score, and CIT Rates ................................................................. 11 


\section{INTRODUCTION}

Excessive corporate debt levels are a serious macroeconomic stability concern. For instance, high debt can increase the probability of a firm's bankruptcy in case of an adverse shock; or it can amplify liquidity constraints after a shock, reflecting larger rollover risks and debt overhang. Giroud and Mueller (forthcoming) report, for example, that the decline in employment during the global financial crisis was significantly more pronounced in highly-leveraged than in lowlyleveraged firms. At the macro level, the excessive corporate debt levels can be seen as systemic credit externalities (Bianchi 2011). Through input-output linkages, a firm's default can spill over to others and amplify aggregate fluctuations in the economy (Acemoglu and others 2012). ${ }^{2}$

Given this concern about excessive corporate debt, it is hard to understand why almost all tax systems around the world encourage the use of corporate debt over equity. Indeed, most corporate income tax (CIT) systems allow interest expenses, but not returns to equity, to be deducted in calculating corporate tax liability. This asymmetry stimulates corporations to use debt over equity to finance investment, beyond levels which they would have otherwise chosen. Empirical studies generally confirm this "debt bias." For instance, meta studies by De Mooij (2011) and Feld and others (2013) find that the existing literature yields a typical impact coefficient of the CIT rate on the debt-asset ratio of 0.28 -i.e., debt bias due to a CIT rate of 25 percent (the average in the OECD) would be responsible for a 7 percentage-point higher debt-to-asset ratio in an average corporation.

Debt bias is now widely recognized as a policy concern (IMF 2016a). And several countries have started to implement measures toward addressing it. Effectively, there are two ways in which debt bias can be neutralized: either by treating equity more similar as debt by adding an allowance for corporate equity (ACE); or by treating debt more similar for taxation as equity by denying interest deductibility for corporations. ACE systems have been quite widely advocated by economists and implemented in some countries, such as Belgium, Cyprus, Italy, Switzerland, and Turkey. Evaluations generally suggest that these systems have been effective in reducing debt bias (IMF 2016a, Hebous and Ruf 2015). Yet, many countries are still reluctant to introduce an ACE due to the expected revenue loss associated with a narrower tax base. Other countries have imposed limitations to interest deductibility. In the limit, interest deductibility could be denied entirely so that the CIT would be transformed into a so-called "comprehensive business income tax" (or, when combined with full expensing of investment, an R-base cash-flow tax). However, there is no country in the world with such a system as it would create significant obstacles with international transactions (such as double taxation or double non-taxation) and involve major transitional problems (e.g., what to do with existing debt). Instead of full denial of interest deductibility, countries have therefore implemented partial restrictions which deny interest deductibility beyond a certain fixed level of debt or interest-so-called "thin capitalization rules" (TCRs).

\footnotetext{
${ }^{2}$ Empirically, Sutherland and Hoeller (2012) find that higher leverage ratios in the non-financial corporate sector are associated with a significantly higher probability of recession. Jordà and others (2013) find that the buildup of private credit during expansion periods tend to make subsequent recessions more likely, deeper and longer lasting (see also Bernanke and Campbell 1988, Bianchi 2011, Friedman 1986, and IMF 2016b).
} 
By raising the cost of debt finance for affected companies, TCRs are believed to reduce corporate debt ratios. This study examines whether indeed TCRs are successful in doing so. A small existing empirical literature assesses the implications of TCRs. Weichenrieder and Windischbauer (2008) study German TCRs and find that they have reduced intracompany loans by foreign affiliates located in Germany. Buettner and others (2012) find evidence for the effects of TCRs on intragroup lending of German outbound FDI. Blouin and others (2014) find similar results for U.S. affiliates abroad. These studies, however, use unconsolidated accounts of companies and their focus is on intragroup lending from affiliates in low to those in high tax countries. This so-called "debt shifting" differs from the debt bias referred to above in that it is a form of tax avoidance by multinationals, induced by cross-country differences in CIT rates. ${ }^{3}$ While important for the tax base, this debt shifting is probably of lesser relevance for macroeconomic stability. Indeed, as there is generally risk-sharing within the multinational group, debt shifting though internal borrowing likely has only limited stability implications (Huizinga and others 2008). ${ }^{4}$

This study concentrates on debt bias, which relates to third-party or external debt of the firm or of the group as a whole. To explore the impact of TCRs on this debt bias, we use consolidated instead of unconsolidated accounts. In the consolidated accounts, all intracompany transactions are excluded and debt ratios represent the external debt position of the entire group. The empirical analysis exploits panel data for non-financial firms in 60 countries between 2005 and 2014-a period in which several countries introduced TCRs.

TCRs vary between countries in various dimensions, such as the strictness of the rule, the definition of the fixed ratio, exemptions and opportunities for carry forward of unused interest. TCR also vary regarding the scope of interest that is restricted, namely whether this applies to interest on all debt or only on intracompany debt. This paper assesses the effectiveness of especially this latter aspect of different TCRs in addressing debt bias. The expectation is that TCRs that impose restrictions to the deductibility of all corporate debt reduce debt bias, while TCRs that only limit deductibility of intra-group interest do not. Yet, we also conjecture that TCRs that restrict the deductibility of intragroup lending can indirectly induce firms to raise external debt by using so-called back-to-back loans. These are essentially intracompany loans, but channeled between affiliates through a third party in order to circumvent a TCR. The empirical analysis will shed light on whether this is indeed a systematically relevant issue in practice.

Furthermore, this paper examines whether the effects of TCRs differ across industries. In particular, we expect the impact of TCRs to be larger in industries with a higher degree of tangibility of assets. The reason is that firms in these industries will find it relatively easier to

\footnotetext{
${ }^{3}$ Debt shifting is addressed in Action 4 of the OECD/G20 initiative on Base Erosion and Profit Shifting, see OECD 2015. The report suggests the adoption of a TCR that restricts interest deductibility if interest-toearnings exceeds a certain fixed ratio. It also proposes a so-called 'group escape', which would nullify the application of the TCR for an affiliate if the ratio for the group as a whole exceeds the fixed TCR ratio. Effectively, therefore, the group's actual external leverage forms the cap for the application of the TCR. Thus, it may help to limit debt shifting within a multinational group, but will not restrict external borrowing by the group as a whole.

${ }^{4}$ Merlo and others (2015) study the effects of TCRs on the location decision of new multinational affiliates using German data. Haufler and Runkel (2012) theoretically show that coordinating TCRs across countries improves welfare, but may intensify tax rate competition.
} 
borrow because they can put up more tangible assets as collateral. With higher a debt ratio, a TCR might more often be binding in these industries and thus have a more pronounced effect on debt ratios. We test this by estimating a difference-in-difference equation in the spirit of Rajan and Zingales (2005) by interacting the variation in tangibility between industries with the TCRs.

Finally, this paper extends the analysis of TCRs beyond their impact on debt ratios. In particular, we explore also the effects of TCRs on a more comprehensive indicator of a firm's financial distress, based on the Altman Z-score (Altman 1968, Altman and others 2015). This score assigns weights to different key firms' financial ratios (of which the debt ratio is one) that are significant predictors of corporate bankruptcy. The reason to explore this comprehensive indicator is that, while TCRs may limit a firm's financial distress by replacing corporate debt by equity, they might induce firms to simultaneously adjusts other behaviors that influence riskiness. The extended analysis will examine whether the balance of these effects still implies a higher bankruptcy risk.

The results of this paper suggest that a TCR that applies only to realted-party debt has no significant impact on external borrowing of corporate groups. Further, such a TCR-has no effect on firm financial distress as measured by the Z-scores. TCRs that target a broader corporate debt base are estimated to reduce the consolidated debt ratio by about 5 percentage points, on average. Further, the evidence indicates that debt ratios are more responsive to TCRs in industries characterized by a high share of tangible assets-reflecting a higher propensity to borrow against collateral. Overall, the findings of this paper suggest that if TCRs are introduced to neutralize tax systems with respect to financing decisions, in many countries their scope should be broadened to cover all debt.

\section{BACKGROUND: THIN-CAPITALIZATION RULES}

Today, 60 countries implement some kind of TCR. Table 1 shows the various forms of TCRs, their date of introduction and information about their strictness. The Table distinguishes between TCRs in two dimensions. The first is whether a rule restricts interest deduction for only relatedparty debt or if it adopts a broader definition of debt potentially restricting all debt. The empirical analysis focuses on this. The second dimension is which ratio determines whether an interest deduction is denied, i.e., whether it is based on a fixed debt-equity ratio, a fixed interestearning ratio ("earning stripping rules") or an arm's-length ratio. There are other relevant dimensions of TCRs, which might matter too for their impact. However, these are more difficult to capture in a quantitative analysis. For instance, the strictness of fixed debt-equity ratios tends not to significantly vary over time, while its meaning depends on whether the rule restricts only related-party debt or total debt. Several TCRs also combine fixed ratios with other tests, making the value of the ratio per se an imprecise distinction between TCRs. 
Table 1. Thin Capitalization Rules in 2016

\begin{tabular}{|c|c|c|c|}
\hline Thin Cap Rule Type & Country & $\begin{array}{c}\text { Year of } \\
\text { Introduction }^{1}\end{array}$ & $\begin{array}{c}\text { Equity-Debt Ratio / EBITDFA } \\
\text { Percentage }\end{array}$ \\
\hline \multirow{33}{*}{$\begin{array}{l}\text { Fixed debt-equity rule for related-party } \\
\text { debt }\end{array}$} & Argentina & 1999 & $2: 1$ \\
\hline & Belarus & 2013 & $1: 1$ \\
\hline & Brazil & 2011 & $2: 1$ \\
\hline & Canada & 1972 & $1.5: 1$ \\
\hline & Chile & 2012 & $3: 1$ \\
\hline & China & 2008 & $2: 1$ \\
\hline & Czech Republic & 2007 & $4: 1$ \\
\hline & Ecuador & 2007 & $3: 1$ \\
\hline & Egypt & 2005 & $4: 1$ \\
\hline & El Salvador & 2012 & $3: 1$ \\
\hline & France $^{2}$ & 2007 & $1.5: 1$ \\
\hline & Ghana & 2000 & $2: 1$ \\
\hline & Gibraltar & 2010 & $5: 1$ \\
\hline & Kenya $^{3}$ & 2006 & $3: 1$ \\
\hline & Korea, Republic of & 1997 & $2: 1$ \\
\hline & Lithuania & 2002 & $4: 1$ \\
\hline & Macedonia & & $3: 1$ \\
\hline & Mexico $^{4}$ & 2005 & $3: 1$ \\
\hline & Mongolia & 2005 & $3: 1$ \\
\hline & Mozambique & 2008 & $2: 1$ \\
\hline & Namibia & 2012 & $3: 1$ \\
\hline & Oman & 2012 & $2: 1$ \\
\hline & Peru & 2007 & $3: 1$ \\
\hline & Poland $^{5}$ & 1999 & $1: 1$ \\
\hline & Rwanda & 2008 & $4: 1$ \\
\hline & Slovenia & 2005 & $4: 1$ \\
\hline & Sri Lanka & 2006 & $3: 1$ \\
\hline & Taiwan & 2011 & $3: 1$ \\
\hline & Turkey & 2006 & $3: 1$ \\
\hline & Uganda & 2013 & $1.5: 1$ \\
\hline & United States & 1989 & $1.5: 1$ \\
\hline & Venezuela & 2007 & $1: 1$ \\
\hline & Yemen & 2010 & $7: 3$ \\
\hline \multirow{17}{*}{ Fixed debt-equity rule for total debt } & Albania & 2000 & $4: 1$ \\
\hline & Australia $^{6}$ & 1997 & $1.5: 1$ \\
\hline & Bulgaria & 2006 & $3: 1$ \\
\hline & Colombia & 2013 & $3: 1$ \\
\hline & Croatia & 2005 & $4: 1$ \\
\hline & Denmark $^{7}$ & 1998 & $4: 1$ \\
\hline & Dominican Republic & 2013 & $3: 1$ \\
\hline & Georgia & 2018 (planned) & $3: 1$ \\
\hline & Hungary & 2000 & $3: 1$ \\
\hline & Indonesia & 2016 & $4: 1$ \\
\hline & Japan $^{8}$ & 1992 & $3: 1$ \\
\hline & Latvia & 2003 & $4: 1$ \\
\hline & New Zealand ${ }^{9}$ & 1995 & $1.6: 1$ \\
\hline & Papua New Guinea & 2013 & $2: 1$ \\
\hline & Romania $^{10}$ & 2006 & $3: 1$ \\
\hline & Serbia & 2001 & $4: 1$ \\
\hline & Zimbabwe & 2011 & $3: 1$ \\
\hline \multirow{3}{*}{ Arm's-length rule } & Kazakhstan & 2008 & \\
\hline & South Africa & 1995 & \\
\hline & United Kingdom & 1999 & \\
\hline \multirow{5}{*}{ Interest-stripping rule for total debt } & Germany & 1994 & $30 \%$ \\
\hline & Greece & 2010 & $40 \%$ \\
\hline & Italy & 2003 & $30 \%$ \\
\hline & Portugal $^{11}$ & 1996 & $30 \%$ \\
\hline & Spain $^{11}$ & 1996 & $30 \%$ \\
\hline \multirow{3}{*}{$\begin{array}{l}\text { Interest-stripping rule for related-party } \\
\text { debt }\end{array}$} & Finland & 2013 & $25 \%$ \\
\hline & Norway & 2014 & $30 \%$ \\
\hline & Slovakia & 2015 & $25 \%$ \\
\hline
\end{tabular}

${ }^{1}$ The TCR in the year of introduction may differ from the one applied in 2016. For example, Germany introduced a TCR in 1994 in the form of a safe-harbor ratio. The interest stripping rule was introduced in 2008.

${ }^{2}$ Has both interest-EBITDA and equity-debt ratios. 
The academic literature on the distortions associated with interest deductibility has considered various alternative policy options. Most of them are meant to restrain intragroup interest deduction and are not targeted to address debt bias. One such option is to use formula apportionment of the worldwide interest expenses, i.e., the worldwide interest of the multinational group would be allocated across its affiliates based on the location of assets, external debt or other variables, such as gross profits or employment. Another option is to adopt a net financing deduction approach. This would deny interest deduction if the borrowing of a firm is used to finance an equity injection in foreign affiliates (Desai and Dharmapala 2015). Third, countries could agree to allow interest on intracompany debt to be deducted only at the tax rate at which the interest income is taxable, i.e., in the country from which is borrowed, to eliminate incentives for debt shifting (IMF 2016a). Finally, a group-wide test could restrict interest deductibility of an affiliate in accordance to its share in the group's worldwide activity. A similar rule is a worldwide cap, but it differs in that it denies the deduction of interests that exceed the worldwide third-party interest expense of the group.

\section{Methodology AND DATA}

\section{A. Empirical Specification}

This section discusses our empirical strategy to identify the impact of TRCs on corporate debt ratios. The analysis is based on three specifications. The first follows the firm-panel model according to:

$$
d e b t_{i s c t}=a_{0}+a_{1}^{j} T C R_{c t}^{j}+a_{2} \operatorname{Tax}_{c t}+\boldsymbol{\beta} \boldsymbol{X}_{\text {isct }}+\lambda_{t}+\mu_{s}+\varepsilon_{i s c t},
$$

where $d e b t_{i s c t}$ is the consolidated total debt-asset ratio of firm $i$ in sector $s$ and resident in country $c$ in year $t$. The variable $T C R_{c t}$ takes the value 1 if a country adopts a thin capitalization rule in year $t$, and is zero otherwise. Tax $x_{c t}$ is the statutory CIT rate. $\boldsymbol{X}_{\text {isct }}$ is a vector of controls with an associated vector of coefficients $\boldsymbol{\beta}$. Equation (1) includes year fixed effects $\left(\lambda_{t}\right)$ that capture all year-specific effects that are common across all firms in the sample (e.g., changes in oil prices or global economic shocks). Further, equation (1) includes sector fixed effects $\left(\mu_{s}\right)$ that capture industry-specific time-invariant effects such as the capital intensity and external financial dependence. We also estimate a variant of equation (1) that includes industry-year fixed effects $\left(\theta_{s t}\right)$ and hence allows industry-specific effects to vary over years.

The coefficient $a_{2}$ is expected to have a positive effect on the consolidated debt ratio, depicting debt bias. Note, however, that the tax rate in country $i$ may be an imperfect tax measure for a firm that operates in more than one country. Hence, there can be measurement error in the tax variable (see also Heckemeyer and De Mooij 2017). However, for the link between stability and debt bias in the home economy, this measurement issue is not crucial in that ultimately it is the association between domestic tax rate and consolidated debt that matters.

Our main coefficient of interest is $a_{1}^{j}$, where $j$ stands for the TCR type. The analysis distinguishes between two types: (i) a total-debt TCR, defined as a TCR that applies to the total debt ratio or a broad definition of debt ( $j=$ thinCap-total); and (ii) a related-party TCR, which applies only to 
related-party debt $(j=$ thinCap-related-party). Both TCR variables are included in equation (1). We also run regressions whereby we do not distinguish between the two types, which we refer to as $j=$ thinCap-all. A negative $\alpha_{1}^{j}$, indicates that a TCR lowers the consolidated debt ratio of the group. This might be expected for $a_{1}^{\text {thincap_total }}$. However, the expected impact of a related-party TCR on debt ratios in the consolidated statement is a priori unclear (i.e., $a_{1}^{\text {thincap-related-party }}$ is ambiguous). In particular, such a TCR does not directly restrict interest deductibility associated with external debt. Yet, restrictions to related party interest might indirectly affect external debt. For example, they may induce firms to use so-called back-to-back loans, which are essentially intragroup loans, but channeled through a third party. The debt of the borrowing affiliate would then be recorded as external debt and not subject to the TCR. Whether such substitution of intracompany debt by back-to-back loans is important is an empirical question. We will explore this by testing whether $\alpha_{1}^{j}$ is positive for $j$ = thinCap-related-party.

As with the tax rate variable, our TCR variable may suffer from measurement error in the sense that it only captures the rules applied in the country where the headquarter of the group is located. Of course, TCRs applied to subsidiaries in other countries could also affect the firm's consolidated debt ratio. In the absence of country-by-country accounts, however, we are unable to identify the TCRs of other countries relevant for the group. When interpreting the results, the coefficient should thus reflect the impact of the TCR in the headquarter country on the group's consolidated debt ratio.

Our second model is a difference-in-difference specification in the spirt of Rajan and Zingales (1998). It exploits variations generated by an interaction term between an industry-specific variable and our country-level tax variables:

$$
d e b t_{i s c t}=\beta_{0}+\beta_{1}\left(\operatorname{Tang}_{s} \times \operatorname{Tax}_{c t}\right)+\beta_{2}\left(\operatorname{Tang}_{s} \times T C R_{c t}\right)+\theta_{s}+\psi_{c t}+e_{i s c t} .
$$

The industry-specific variable $\mathrm{Tang}_{s}$ is a tangibility index, computed as the industry median share of tangible assets in total assets at the level of NACE revision 2 using U.S. data as in Rajan and Zingales (1998). Its base effect is captured by the industry fixed effects $\left(\theta_{s}\right)$. All country-year specific variables such as TCR and Tax are captured by the set of country-year fixed effects $\psi_{c t}$. The coefficients $\beta_{1}$ and $\beta_{2}$ on the interaction terms give the differential effects of taxes and TCRs on the consolidated debt ratio, varying by the degree of tangibility in the industry. Companies in industries characterized by a relatively high degree of tangibility can provide more collateral and hence may have more room for using debt finance than companies in low tangibility sectors. A positive $\beta_{1}$ would imply that this would also make them relatively more responsive to taxes Similarly, a negative $\beta_{2}$ would mean that the debt ratios of companies in high tangibility sectors are more negatively affected by TCRs, presumably as they are more often restricted. Again, we explore this for both $j=$ thinCap-total and $j=$ thinCap-related-party.

Finally, we explore the impact of taxation in a regression that is similar to equation (1), but based on a more comprehensive measure of financial distress, the so-called Z-score. The underlying idea is that, while taxes may raise debt ratios due to debt bias, firms may (partly) offset the effect this has on bankruptcy risk by adjusting risk exposure through other choices affecting bankruptcy risk. By exploring the Z-score, the net impact on default risk is analyzed. In doing so, 
the popular bankruptcy prediction model of the Altman Z-score is used. This model identifies ratios that are significant predictors of corporate bankruptcy in manufacturing sectors based on a multiple discriminate analysis. Following the literature (for example, Altman and others 2014), the Altman's Z-score (Z) for each firm in each year is calculated as follows:

$$
Z=3.25+6.56 X_{1}+3.26 X_{2}+6.72 X_{3}+1.05 X_{4}
$$

where $X_{1}$ is the ratio of working capital to total assets, $X_{2}$ is the ratio of retained earnings to total assets, $X_{3}$ is the ratio of earnings before interest and taxes to total assets, and $X_{4}$ is the ratio of the book value of equity to the book value of total liabilities. A high $Z$ indicates a lower risk of failure. For robustness, we also compute an alternative Altman's $Z$-score (denoted by $Z$ ) and augment the discriminant function with sales $\left(X_{5}\right)$ as in Bernanke and Campbell (1988) and the original contribution by Altman (1968):

$$
Z^{\prime}=1.2 X_{1}+1.4 X_{2}+3.3 X_{3}+0.6 X_{4}+1.0 X_{5}
$$

where $X_{5}$ is the ratio of sales to total assets. Low values of $Z^{\prime}$ indicate financial distress of companies and higher likelihoods of bankruptcy.

Bankruptcy risks are likely to rise in a non-linear fashion in the Z-score. Therefore, we use the Altman Z-scores from either (3) or (4) to define a binary variable that reflects the presence of high bankruptcy risk or not. In particular, the literature suggests that firms with a $Z$ value lower than 2 are in the zone of financial turmoil and close to bankruptcy. In our sample this corresponds to the $7^{\text {th }}$ percentile of the Z-score. We set the cut-off point in equation (3) and (4) such that firms with a $Z$-score below the $7^{\text {th }}$ percentile are indeed in financial distress (dummy 1 ) and all others are not (dummy 0 ). We then estimate the effect of TCRs on the likelihood of a firm to face financial distress. This approach has the advantage that it focuses on the impact of high financial risk, rather than a marginal change to the index itself.

As indicted in John and others (2008), the volatility of corporate earnings is an ex-post measure of risk taking. Thus, in the analysis, we include volatility as an explanatory variable for the financial distress indicator. As in John and others (2008), we construct this measure as the deviation of the firm's EBITDA/Assets from the country average in a given year, and then calculate the standard deviation of this measure, for each firm, on a three-year rolling window:

$$
\begin{array}{r}
\text { Volatility }=\sqrt{\frac{1}{T} \sum_{1}^{T}\left(E_{\text {isct }}-\frac{1}{T} \sum_{1}^{T} E_{\text {isct }}\right)^{2}}, \\
\text { where } E_{\text {isct }}=\frac{\text { EBIDTA }_{i s c t}}{\text { TotalAsset }_{\text {isct }}}-\frac{1}{N} \sum_{1}^{T} \frac{\text { EBIDTA }_{\text {isct }}}{\text { TotalAssets }_{\text {isct }}} .
\end{array}
$$

\section{B. Data}

The source of the firm-level data is the ORBIS database of the Bureau van Dijk. It contains, inter alia, information on companies' balance sheet items, types of accounts (consolidated versus unconsolidated), and the economic sector of the company. The sample in the analysis includes consolidated accounts for 369,757 observations corresponding to about 100,000 distinct firms in 
60 countries in the period from 2005 to 2014 . As TCRs in many countries do not apply to the financial sector, the analysis includes only non-financial firms. To control for outliers, variables are winsorized at the 0.5 percent level. Table 2 provides summary statistics of the main variables. The average consolidated debt-to-assets ratio in the sample is 62 percent whereas the median is slightly lower at around 60.2 percent. The sample size of the Z-score is notably smaller due to limited data availability of the underlying ratios - the ultimate sample has around 45,000 observations.

Table 2. Summary Statistics

\begin{tabular}{|c|c|c|c|c|c|c|}
\hline VARIABLES & Mean & SD & Median & Min & Max & $\mathbf{N}$ \\
\hline debtRatio & 62.09 & 36.18 & 60.16 & 4.380 & 226.1 & 369,757 \\
\hline citRate & 27.39 & 5.217 & 28 & 8.500 & 39 & 369,757 \\
\hline ThinCap-all & 0.688 & 0.463 & 1 & 0 & 1 & 358,978 \\
\hline ThinCap-total & 0.174 & 0.380 & 0 & 0 & 1 & 358,978 \\
\hline ThinCap-related-party & 0.514 & 0.500 & 1 & 0 & 1 & 358,978 \\
\hline Volatility & 0.0771 & 0.170 & 0.035 & 0.000242 & 1.647 & 264,432 \\
\hline Z-score & 5.394 & 7.026 & 6.418 & -26.32 & 16.16 & 115,924 \\
\hline$Z^{\prime}$-score & 1.930 & 3.203 & 2.265 & -11.80 & 7.577 & 115,511 \\
\hline Financial distress-Z & 0.075 & 0.263 & 0 & 0 & 1 & 44,590 \\
\hline Financial distress-Z' & 0.101 & 0.302 & 0 & 0 & 1 & 45,283 \\
\hline interestRateReal & 2.062 & 4.046 & 2.295 & -42.31 & 44.55 & 272,556 \\
\hline gdpGrowth & 2.607 & 8.135 & 2.532 & -51.45 & 32.68 & 369,757 \\
\hline inflationCpi & 2.815 & 2.685 & 2.321 & -1.706 & 34.73 & 369,757 \\
\hline InOperatingRev & 17.65 & 2.247 & 17.75 & 11.29 & 21.93 & 369,757 \\
\hline ebitdaShareOfAssets & 6.067 & 21.17 & 8.701 & -114.5 & 35.42 & 369,757 \\
\hline
\end{tabular}

We merge the firm-level data with macroeconomic variables such as inflation and GDP growth obtained from the IMF's World Economic Outlook database and real interest rate data from the World Bank World Development Indictors. Data on TCRs and statutory CIT rates are from the IMF's Fiscal Affairs Department database. The mean of the statutory CIT rate in the sample is 27.4 percent. It has a minimum value of 8.5 percent and a maximum value of 39 percent (Table 2). TCRs have been introduced in several countries in our sample period between 2005 and 2014 (Table 1). ThinCap-all is a variable that depicts whether or not a country embraces a TCR, irrespective of its type. The variable ThinCap-total is equal to one if the TCR rule applies to total debt, zero otherwise. ThinCap-related-party is equal to one if the TCR applies only to related-party debt, zero otherwise. 
Figure 1. Binned Scatter Plots of Debt Ratios, Z-Score, and CIT Rates
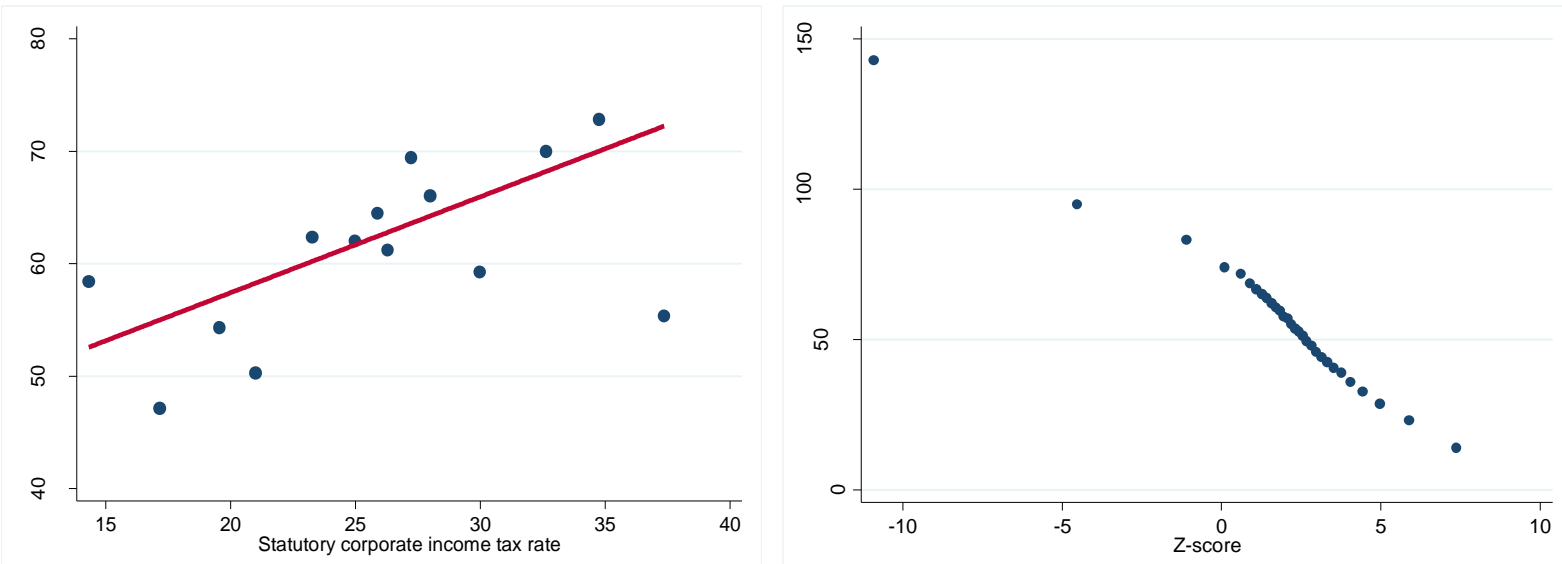

The left panel of Figure 1 displays a binned scatter plot of corporate debt ratios and CIT rates in our sample. There is a clear positive correlation between both variables, consistent with the presence of debt bias. The right panel of Figure 1 shows a strong negative correlation between the Z-score and the debt ratio implying that highly leveraged companies have a low Z-score, i.e., they face higher financial distress and bankruptcy risks.

\section{RESUlts}

Table 3 presents results from estimating (1) using the consolidated debt ratio as the dependent variable. Robust standard errors are in parentheses. The Table presents six regressions that vary in the type of TCR that is included and in the use of different sets of fixed effects to control for unobserved heterogeneity. In all regressions, the coefficient for the CIT rate is positive and significant, with values around 0.3. Hence, lowering the statutory CIT rate by 10 percentage points leads to a reduction of the debt ratio by 3 percentage points. This estimated impact is very close to the average value reported in the meta analyses of De Mooij (2011) and Feld and others (2013). 
Table 3. Thin Capitalization Rules and Corporate Debt Ratio

\begin{tabular}{|c|c|c|c|c|c|c|}
\hline \multirow[t]{2}{*}{ Dependent Variable } & \multicolumn{6}{|c|}{ Debt Ratio } \\
\hline & (1) & (2) & (3) & (4) & (5) & (6) \\
\hline \multirow[t]{2}{*}{ ThinCap—all } & $-1.333^{\star * *}$ & & & $-1.062^{*}$ & & \\
\hline & $(0.178)$ & & & $(0.624)$ & & \\
\hline \multirow[t]{2}{*}{ ThinCap-total } & & $-5.129 \star \star \star$ & $-5.634^{\star \star \star}$ & & $-5.075^{\star \star \star}$ & $-5.360^{\star \star \star}$ \\
\hline & & $(0.171)$ & $(0.225)$ & & $(0.597)$ & $(0.719)$ \\
\hline \multirow[t]{2}{*}{ ThinCap_related-party } & & & $-0.590^{\star \star \star}$ & & & -0.332 \\
\hline & & & $(0.180)$ & & & $(0.633)$ \\
\hline \multirow[t]{2}{*}{ citRate } & $0.301^{\star \star \star}$ & $0.308^{\star \star \star}$ & $0.313^{\star \star \star}$ & $0.283^{\star \star \star}$ & $0.293^{\star \star \star}$ & $0.296^{\star \star \star}$ \\
\hline & $(0.0182)$ & $(0.0181)$ & $(0.0182)$ & $(0.0492)$ & $(0.0485)$ & $(0.0501)$ \\
\hline \multirow[t]{2}{*}{ gdpGrowth } & $-0.178^{\star \star \star}$ & $-0.203^{\star \star \star}$ & $-0.210^{\star \star \star}$ & $-0.177^{\star \star \star}$ & $-0.205^{\star \star \star}$ & $-0.209 * \star \star$ \\
\hline & $(0.0105)$ & $(0.0106)$ & $(0.0107)$ & $(0.0438)$ & $(0.0420)$ & $(0.0422)$ \\
\hline \multirow[t]{2}{*}{ inflationCpi } & $0.921^{* \star *}$ & $0.703^{\star * \star}$ & $0.661^{* * *}$ & $0.992^{\star \star *}$ & $0.752^{* * *}$ & $0.728^{* * *}$ \\
\hline & $(0.0408)$ & $(0.0426)$ & $(0.0431)$ & $(0.118)$ & $(0.126)$ & $(0.127)$ \\
\hline \multirow[t]{2}{*}{ ebitdaShareOfAssets } & $-0.728^{\star \star \star}$ & $-0.726^{\star \star \star}$ & $-0.727^{\star \star \star}$ & 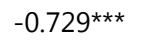 & $-0.728^{\star \star \star}$ & 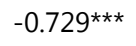 \\
\hline & $(0.00663)$ & $(0.00658)$ & $(0.00660)$ & $(0.00954)$ & $(0.00986)$ & $(0.00959)$ \\
\hline \multirow[t]{2}{*}{ operatingRevenueRatio } & $-0.255^{\star \star *}$ & $-0.187^{\star \star \star}$ & $-0.196^{\star \star *}$ & $-0.252^{\star \star \star}$ & $-0.187^{\star \star \star}$ & $-0.192^{* \star *}$ \\
\hline & $(0.0193)$ & $(0.0189)$ & $(0.0192)$ & $(0.0452)$ & $(0.0406)$ & $(0.0407)$ \\
\hline \multirow[t]{2}{*}{ interestRateReal } & $1.587^{\star \star \star}$ & $1.673^{\star \star \star}$ & $1.681^{\star \star *}$ & $1.586^{\star \star \star}$ & $1.674^{\star \star \star}$ & $1.678^{\star \star \star}$ \\
\hline & $(0.0449)$ & $(0.0448)$ & $(0.0449)$ & $(0.128)$ & $(0.127)$ & $(0.128)$ \\
\hline \multirow[t]{2}{*}{ Constant } & $35.00^{\star \star \star *}$ & $33.67^{\star \star \star}$ & $33.60^{\star * *}$ & $28.20^{\star \star \star}$ & $27.10^{\star \star \star}$ & $27.28^{\star \star \star}$ \\
\hline & (12.92) & $(12.82)$ & $(12.82)$ & (2.936) & (3.044) & $(2.967)$ \\
\hline Observations & 262,727 & 262,727 & 262,727 & 262,727 & 262,727 & 262,727 \\
\hline$R^{2}$ & 0.184 & 0.186 & 0.186 & 0.163 & 0.165 & 0.165 \\
\hline Industry & Yes & Yes & Yes & & & \\
\hline Year & Yes & Yes & Yes & & & \\
\hline Industry-year FE & & & & Yes & Yes & Yes \\
\hline
\end{tabular}

In column (1), the estimated coefficient for the TCR variable of 1.3 suggests that the presence of some form of TCR reduces the consolidated debt ratio on average by about 1.3 percentage points. Column (2) suggests that a TCR applying to total debt, with a coefficient of 5.1, has a much stronger negative effect on consolidated corporate debt than do the generality of TCRs. In column (3), this effect is similar and can be compared with the coefficient for related-party TCRs, which is only one-tenth of that. A Wald test strongly rejects the hypothesis that there is no difference between total-debt and related-party TCRs (with a p-value of 0.00 ). Columns (4) to (6) in Table 2 are the same as columns (1) to (3), except that they include industry-year fixed effects allowing industry shocks to be year-specific instead of industry and year fixed effects. The main 
results carry over, except that the coefficient for related-party TCRs become statistically insignificant. Hence, the results indicate that total-debt TCRs help to address debt bias, with a robustly significant and large negative coefficient. However, the effect of related party-TCRs is less clear-cut and much smaller in size. Also, there is no indication that related-party TCRs indirectly increase external debt through the use of back-to-back loans.

Table 4. Thin Capitalization Rules and Tangibility: A Difference-in-Difference Specification

\begin{tabular}{|c|c|c|c|c|}
\hline \multirow[t]{2}{*}{ Dependent Variable } & \multicolumn{4}{|c|}{ Debt Ratio } \\
\hline & (1) & (2) & (3) & (4) \\
\hline thinCapAll $\times$ tangibility & & $\begin{array}{l}-0.0261^{*} \\
(0.0133)\end{array}$ & & \\
\hline thinCapTotal $\times$ tangibility & & & $\begin{array}{c}-0.0853^{* * *} \\
(0.0226)\end{array}$ & $\begin{array}{c}-0.0888^{* * *} \\
(0.0233)\end{array}$ \\
\hline $\begin{array}{l}\text { thinCapRelatedParty } \times \\
\text { tangibility }\end{array}$ & & & & $\begin{array}{r}-0.00557 \\
(0.0139)\end{array}$ \\
\hline citrate $\times$ tangibility & $\begin{array}{l}0.0064^{\star * \star} \\
(0.00141)\end{array}$ & $\begin{array}{l}0.0064^{\star * *} \\
(0.00145)\end{array}$ & $\begin{array}{l}0.0057^{* * *} \\
(0.00133)\end{array}$ & $\begin{array}{l}0.0057^{* * *} \\
(0.00131)\end{array}$ \\
\hline ebitdaShareOfAssets & $\begin{array}{l}-0.767^{* * *} \\
(0.0249)\end{array}$ & $\begin{array}{l}-0.763^{* * *} \\
(0.0251)\end{array}$ & $\begin{array}{l}-0.764^{* * *} \\
(0.0250)\end{array}$ & $\begin{array}{l}-0.764^{* * *} \\
(0.0250)\end{array}$ \\
\hline operatingRevenueRatio & $\begin{array}{c}1.978^{\star \star \star} \\
(0.158)\end{array}$ & $\begin{array}{c}1.892^{\star * \star} \\
(0.159)\end{array}$ & $\begin{array}{c}1.886^{\star * *} \\
(0.159)\end{array}$ & $\begin{array}{c}1.886^{\star * *} \\
(0.159)\end{array}$ \\
\hline Constant & $\begin{array}{c}21.67^{\star \star \star} \\
(2.881)\end{array}$ & $\begin{array}{c}23.21^{* * *} \\
(2.906)\end{array}$ & $\begin{array}{c}23.59 * \star * \\
(3.011)\end{array}$ & $\begin{array}{c}23.64^{\star * *} \\
(2.989)\end{array}$ \\
\hline Observations & 369,757 & 358,978 & 358,978 & 358,978 \\
\hline$R^{2}$ & 0.169 & 0.169 & 0.169 & 0.169 \\
\hline Industry FE & Yes & Yes & Yes & Yes \\
\hline Country-year FE & Yes & Yes & Yes & Yes \\
\hline
\end{tabular}

Note: This table shows results from estimating a difference-in-difference specification described in equation (2). ThinCap-all is a variable that depicts whether or not a country embraces a TCR. The variable ThinCap-total is equal to one if the TCR rule applies to total debt, zero otherwise. ThinCap-related-party is equal to one if the TCR applies only to related-party debt, zero otherwise. CitRate is the statutory corporate income tax rate. Data are from ORBIS for 2005-14. The variable tangibility is an industry-specific index that captures industry needs for external financing as in Rajan and Zingales (1998). Robust standard errors are in parentheses. ${ }^{* *} \mathrm{p}<0.01,{ }^{* *} \mathrm{p}<0.05,{ }^{*} \mathrm{p}<0.1$.

Table 4 reports results from estimating specification (2). In all columns, the estimated effect of the interaction term between taxes and tangibility on the consolidated debt ratio is positive, suggesting that debt bias is higher in capital-intensive industries, i.e., firms that rely more heavily on tangible assets react more strongly to corporate tax rates. This is perhaps because they have 
relatively easier access to credit. Column (2) adds the interaction between the TCR-variable and tangibility. This coefficient is statistically significant and negative. It implies that TCRs reduce debt ratios differentially more in industries with higher tangibility. These firms are more likely to be constrained in light of their higher debt ratios. Columns (3) and (4) show that this finding is driven solely by TCRs that apply to total debt; the coefficient for related-party TCRS is statistically insignificant.

To get a sense of the estimated magnitude of the interaction term, consider the partial effect of a TCR applied to total debt on the debt ratio: $\frac{\partial d e b t}{\partial \text { thinCapTotal }}=$ BaseEffect $+\beta_{2}$ (Tang). The base effect is nested in the fixed effects. The estimated $\beta_{2}$ in column 4 , for example, is -0.088 . We can retrieve a magnitude of the interaction effect by evaluating the partial effect at two different levels of tangibility and taking the difference. For instance, the implied interactive effect of ThinCap-total on the debt ratio evaluated at the value of $25^{\text {th }}$ percentile of tangibility is - 0.71 percentage points (i.e., ThinCap-total decreases the debt ratio compared to the base effect and given the $25^{\text {th }}$ percentile level of Tang by 0.71 percentage points). The interactive effect of ThinCap-total on the debt ratio evaluated at the value of $75^{\text {th }}$ percentile of tangibility is -2.2 percentage points indicating that higher tangibility makes the effect of a TCR on the debt ratio higher (i.e., it reduces the debt ratio compared to the base effect and given the $75^{\text {th }}$ percentile level of Tang by 2.2 percentage points). The difference between both interaction effects, in terms of absolute value, is -1.5 percentage points (2.2-0.71).

In Table 5, the dependent variable is the financial distress indicator, based on equation (3) or (4). The columns vary by the estimator (linear probability model versus logit model) and the set of fixed effects. In all columns, the coefficient for the TCR variable for total debt has a negative sign. This indicates a negative effect of these TCRs on financial distress, i.e., a positive effect on the likelihood of a firm to be in the safe zone. For example, the estimates from the linear probability model in columns (1) and (2) suggest that a total-debt TCR reduces the probability of a manufacturing company facing bankruptcy risks by 5 percentage points. Logit estimates yield a similar pattern. The results also indicate that related-party TCRs have no significant effect on the financial distress indicator; in columns (3) and (4), it even appears with the wrong sign. Thus, from the perspective of bankruptcy risk associated with debt bias, total-debt TCRs are found to be effective while TCRs that apply only to related-party debt are not.

Finally, Table 6 shows the difference-in-difference strategy as in Table 4, but using the financial distress indicator as the dependent variable. Table 6 shows only the logit estimates. Results are consistent with the findings in Table 4: total-debt TCRs lower the likelihood of financial distress differentially more for companies in industries with higher tangibility. As expected, higher sales and EBITDA reduce the probability of bankruptcy whereas the volatility measure is associate with a higher likelihood of witnessing a financial turmoil. 
Table 5. Thin Capitalization Rules and Corporate Stability

\begin{tabular}{|c|c|c|c|c|c|c|c|c|}
\hline \multirow{3}{*}{$\begin{array}{l}\text { Financial distress } \\
\text { indicator } \\
\text { based on: }\end{array}$} & \multicolumn{4}{|c|}{$Z$} & \multicolumn{4}{|c|}{$Z^{\prime}$} \\
\hline & \multicolumn{2}{|c|}{ LPM } & \multicolumn{2}{|c|}{ Logit } & \multicolumn{2}{|c|}{ LPM } & \multicolumn{2}{|c|}{ Logit } \\
\hline & (1) & (2) & (3) & (4) & (5) & (6) & (7) & (8) \\
\hline thinCap-total & $\begin{array}{c}-0.050^{* * *} \\
(0.009)\end{array}$ & $\begin{array}{c}-0.050^{* * *} \\
(0.004)\end{array}$ & $\begin{array}{c}-0.095^{* * *} \\
(0.002)\end{array}$ & $\begin{array}{c}-0.095^{\star \star \star} \\
(0.028)\end{array}$ & $\begin{array}{c}-0.066^{\star * \star} \\
(0.011)\end{array}$ & $\begin{array}{c}-0.067^{* * *} \\
(0.005)\end{array}$ & $\begin{array}{c}-0.119^{* *} \\
(0.051)\end{array}$ & $\begin{array}{c}-0.119^{* * *} \\
(0.004)\end{array}$ \\
\hline thinCap-related-party & $\begin{array}{l}-0.003 \\
(0.012)\end{array}$ & $\begin{array}{l}-0.003 \\
(0.006)\end{array}$ & $\begin{array}{c}0.001 \\
(0.003)\end{array}$ & $\begin{array}{c}0.002 \\
(0.003)\end{array}$ & $\begin{array}{l}-0.004 \\
(0.016)\end{array}$ & $\begin{array}{l}-0.004 \\
(0.007)\end{array}$ & $\begin{array}{l}-0.002 \\
(0.003)\end{array}$ & $\begin{array}{l}-0.002 \\
(0.003)\end{array}$ \\
\hline citRate & $\begin{array}{l}-0.000 \\
(0.001)\end{array}$ & $\begin{array}{l}-0.001 \\
(0.000)\end{array}$ & $\begin{array}{l}-0.002 \\
(0.002)\end{array}$ & $\begin{array}{l}-0.000 \\
(0.000)\end{array}$ & $\begin{array}{l}-0.000 \\
(0.001)\end{array}$ & $\begin{array}{l}-0.000 \\
(0.000)\end{array}$ & $\begin{array}{l}-0.0002 \\
(0.0003)\end{array}$ & $\begin{array}{l}-0.0002 \\
(0.0003)\end{array}$ \\
\hline gdpGrowth & $\begin{array}{c}-0.002^{* * *} \\
(0.000)\end{array}$ & $\begin{array}{c}-0.002^{* * *} \\
(0.000)\end{array}$ & $\begin{array}{c}-0.002^{* * *} \\
(0.000)\end{array}$ & $\begin{array}{c}-0.002^{* * *} \\
(0.001)\end{array}$ & $\begin{array}{c}-0.002^{* * *} \\
(0.000)\end{array}$ & $\begin{array}{c}-0.002^{* * *} \\
(0.000)\end{array}$ & $\begin{array}{c}-0.002^{* *} \\
(0.000)\end{array}$ & $\begin{array}{l}-0.002^{* *} \\
(0.000)\end{array}$ \\
\hline interestRateReal & $\begin{array}{c}0.002^{* * *} \\
(0.001)\end{array}$ & $\begin{array}{c}0.002^{* * *} \\
(0.001)\end{array}$ & $\begin{array}{c}0.002^{\star * *} \\
(0.000)\end{array}$ & $\begin{array}{c}0.002^{* * *} \\
(0.001)\end{array}$ & $\begin{array}{l}0.002^{* *} \\
(0.001)\end{array}$ & $\begin{array}{c}0.003^{* * *} \\
(0.001)\end{array}$ & $\begin{array}{l}0.002^{* *} \\
(0.000)\end{array}$ & $\begin{array}{l}0.002^{\star *} \\
(0.000)\end{array}$ \\
\hline Volatility & $\begin{array}{c}0.504^{\star * *} \\
(0.047)\end{array}$ & $\begin{array}{c}0.510^{* \star *} \\
(0.030)\end{array}$ & $\begin{array}{c}0.241^{* \star *} \\
(0.010)\end{array}$ & $\begin{array}{c}0.249^{* * *} \\
(0.073)\end{array}$ & $\begin{array}{c}0.636^{\star \star \star} \\
(0.045)\end{array}$ & $\begin{array}{c}0.643^{\star * *} \\
(0.026)\end{array}$ & $\begin{array}{l}0.396^{\star *} \\
(0.0172)\end{array}$ & $\begin{array}{l}0.407^{\star \star} \\
(0.0170)\end{array}$ \\
\hline Constant & $\begin{array}{c}0.078^{* * *} \\
(0.025)\end{array}$ & $\begin{array}{c}0.075^{\star * *} \\
(0.013)\end{array}$ & $\begin{array}{c}-12.82^{* * *} \\
(0.574)\end{array}$ & $\begin{array}{c}-12.55^{* * *} \\
(0.993)\end{array}$ & $\begin{array}{c}0.096^{* \star *} \\
(0.031)\end{array}$ & $\begin{array}{c}0.093^{* * *} \\
(0.016)\end{array}$ & $\begin{array}{l}-14.55 \\
(3.382)\end{array}$ & $\begin{array}{l}-16.62 \\
(1.380)\end{array}$ \\
\hline $\begin{array}{l}\text { Observations } \\
R^{2} \\
\text { Industry and year FE } \\
\text { Industry-year FE }\end{array}$ & $\begin{array}{c}44,590 \\
0.053 \\
\text { Yes }\end{array}$ & $\begin{array}{c}44,590 \\
0.053 \\
\text { Yes }\end{array}$ & $\begin{array}{c}44,589 \\
\text { Yes }\end{array}$ & 44,466 & $\begin{array}{c}45,239 \\
0.072 \\
\text { Yes }\end{array}$ & $\begin{array}{c}45,239 \\
0.072\end{array}$ & $\begin{array}{c}45,238 \\
\text { Yes }\end{array}$ & 45,094 \\
\hline
\end{tabular}

Note: This table shows results from estimating a linear probability model (LPM) or a logit model where the depended variable is a financial distress indicator coded 1 if the $Z$-score of a firm is below the $7^{\text {th }}$ percentile; zero otherwise. In columns 1 to 4 , the indicator is based on $Z$ as given in equation 3 whereas in columns 5 to 8 the indicator is based on $Z^{\prime}$ as given in equation 4. Logit results are reported as marginal effects. Robust standard errors are in parentheses. The variable ThinCap-total is equal to one if the TCR rule applies to total debt, zero otherwise. ThinCap-partial is equal to one if the TCR applies only to related-party debt, zero otherwise. CitRate is the statutory corporate income tax rate. Data are from ORBIS for $2005-14$. ${ }^{* *} p<0.01,{ }^{* *} p<0.05,{ }^{*} p<0.1$.

\section{COnCluding Remarks}

Risks to macroeconomic stability posed by excessive private leverage are significantly amplified by tax distortions. This debt bias has become widely recognized as a stability concern since the global financial crisis. Several countries have therefore started to implement limitations to the deductibility of interest for the corporate income tax through thin capitalization rules (TCRs), as a way to mitigate this bias. This paper explores the effectiveness of these rules. It finds that TCRs can work, but their design matters. For instance, a TCR that restricts interest deductibility of all debt reduces the debt-asset ratio by on average 5 percentage points. However, rules restricting only intracompany interest payments have no discernable effect on external debt. Our results are robust for broader measures of financial distress. Moreover, we find evidence that debt in high tangibility industries is more responsive to TCRs than debt in low tangibility industries.

These results have important policy implications. For instance, if a country introduces a TCR to address the stability concerns related to debt bias, it should apply it to all debt. However, two-thirds of the TCRs observed around the world today are targeted to related-party debt only. 
Hence, while many countries have introduced TCRs to curb debt shifting by multinationals, only few have designed them in a way that also addresses debt bias. Another implication of our results is that a uniform TCR might induce distortions and that differentiation between sectors might be desirable. For instance, firms in different sectors vary in their inherent non-tax corporate financial decisions, e.g. due to variation in tangibility of their assets. Since financial distress might thus arise at different levels of debt, a uniform TCR might be unduly restrictive in some sectors but not sufficiently restrictive in others.

Much is still to be explored regarding the impact of TRCs. For instance, if country-by-country reports were available for multinational corporations, we would be able to explore the impact of TCRs in not only the headquarter country, but also in countries where the subsidiaries reside. Second, other implication of thin capitalization rules, such as effects on investment, should be explored more fully. Finally, as corporate financial structures might vary widely between firms for other reasons than taxation or tangibility, it would be relevant to understand how uniform TCRs affect them differentially. 
Table 6. TCRs, Tangibility, and Corporate Stability-A Diff-in-Diff Specification

\begin{tabular}{|c|c|c|c|c|c|c|c|c|}
\hline \multirow{2}{*}{$\begin{array}{l}\text { Financial distress } \\
\text { indicator } \\
\text { based on: }\end{array}$} & \multicolumn{4}{|c|}{$Z$} & \multicolumn{4}{|c|}{$Z^{\prime}$} \\
\hline & (1) & (2) & (3) & (4) & (5) & (6) & (7) & (8) \\
\hline thinCapAll $\times$ tangibility & & $\begin{array}{c}-0.041^{* * *} \\
(0.009)\end{array}$ & & & & $\begin{array}{c}- \\
0.0410^{\star \star *} \\
(0.0098)\end{array}$ & & \\
\hline $\begin{array}{l}\text { thinCapTotal } \times \\
\text { tangibility }\end{array}$ & & & $\begin{array}{c}-0.263^{* * *} \\
(0.027)\end{array}$ & $\begin{array}{c}-0.263^{* * *} \\
(0.028)\end{array}$ & & & $\begin{array}{c}- \\
0.2772^{\star * *} \\
(0.0267)\end{array}$ & $\begin{array}{c}- \\
0.2748^{* * *} \\
(0.0271)\end{array}$ \\
\hline $\begin{array}{l}\text { thinCapRelatedParty } \times \\
\text { tangibility }\end{array}$ & & & & -0.0006 & & & & 0.0039 \\
\hline Citrate $\times$ tangibility & $\begin{array}{l}0.0053^{* \star \star} \\
(0.0008)\end{array}$ & $\begin{array}{c}0.0050^{\star * *} \\
(0.0009)\end{array}$ & $\begin{array}{c}0.0051^{* * *} \\
(0.0008)\end{array}$ & $\begin{array}{c}(0.009) \\
0.0051^{\star * *} \\
(0.0008)\end{array}$ & $\begin{array}{c}0.0053^{* \star *} \\
(0.0008)\end{array}$ & $\begin{array}{l}0.0048^{* * *} \\
(0.0009)\end{array}$ & $\begin{array}{l}0.0051^{* * *} \\
(0.0008)\end{array}$ & $\begin{array}{c}(0.0100) \\
0.0051^{\star * \star} \\
(0.0008)\end{array}$ \\
\hline ebitdaShareOfAssets & $\begin{array}{c}-0.004^{* * *} \\
(0.000)\end{array}$ & $\begin{array}{c}-0.004^{* * *} \\
(0.000)\end{array}$ & $\begin{array}{c}-0.004^{* * *} \\
(0.000)\end{array}$ & $\begin{array}{c}-0.004^{* * *} \\
(0.000)\end{array}$ & $\begin{array}{c}- \\
0.0053^{\star * \star} \\
(0.0001)\end{array}$ & $\begin{array}{c}- \\
0.0054^{\star * *} \\
(0.0001)\end{array}$ & $\begin{array}{c}- \\
0.0054^{\star \star \star} \\
(0.0001)\end{array}$ & $\begin{array}{c}- \\
0.0054^{\star \star *} \\
(0.0001)\end{array}$ \\
\hline operatingRevenueRatio & $\begin{array}{c}-0.009 * * * \\
(0.000)\end{array}$ & $\begin{array}{c}-0.010^{* * *} \\
(0.000)\end{array}$ & $\begin{array}{c}-0.009 * * * \\
(0.000)\end{array}$ & $\begin{array}{c}- \\
0.0093^{* \star \star} \\
(0.0006)\end{array}$ & $\begin{array}{c}- \\
0.0140^{\star \star \star} \\
(0.0006)\end{array}$ & $\begin{array}{c}- \\
0.0149 * \star \star \\
(0.0006)\end{array}$ & $\begin{array}{c}- \\
0.0139 * \star \star \\
(0.0006)\end{array}$ & $\begin{array}{c}- \\
0.0140^{* \star \star} \\
(0.0006)\end{array}$ \\
\hline Volatility & $\begin{array}{c}0.068^{* * *} \\
(0.010)\end{array}$ & $\begin{array}{c}0.071^{* * *} \\
(0.011)\end{array}$ & $\begin{array}{l}0.062^{\star * \star} \\
(0.011)\end{array}$ & $\begin{array}{c}0.062^{\star * \star} \\
(0.011)\end{array}$ & $\begin{array}{c}0.0784^{* * *} \\
(0.0122)\end{array}$ & $\begin{array}{c}0.0821^{* * *} \\
(0.0130)\end{array}$ & $\begin{array}{c}0.0699 * * * \\
(0.0125)\end{array}$ & $\begin{array}{c}0.0695^{* * *} \\
(0.0126)\end{array}$ \\
\hline Constant & $\begin{array}{c}0.242 \\
(0.448)\end{array}$ & $\begin{array}{c}0.334 \\
(0.450)\end{array}$ & $\begin{array}{c}0.212 \\
(0.450)\end{array}$ & $\begin{array}{c}0.210 \\
(0.450)\end{array}$ & $\begin{array}{c}1.20 \\
(0.369)\end{array}$ & $\begin{array}{c}1.29 \\
(0.371)\end{array}$ & $\begin{array}{c}1.15 \\
(0.371)\end{array}$ & $\begin{array}{c}1.16 \\
(0.371)\end{array}$ \\
\hline Observations & 49,708 & 46,371 & 46,371 & 46,371 & 50,497 & 47,159 & 47,159 & 47,159 \\
\hline Industry FE & Yes & Yes & Yes & Yes & Yes & Yes & Yes & Yes \\
\hline Country-year FE & Yes & Yes & Yes & Yes & Yes & Yes & Yes & Yes \\
\hline
\end{tabular}

Note: This table shows results from estimating a logit model where the dependent variable is a financial distress indicator coded 1 if the $Z$-score of a firm is blow the $7^{\text {th }}$ percentile; zero otherwise. $n$ columns 1 to 4 , the indicator is based on $Z$ as given in equation 3 whereas in columns 5 to 8 the indicator is based on $Z^{\prime}$ as given in equation 4 . Results are reported as marginal effects. Robust standard errors in parentheses. The variable ThinCap-total is equal to one if the TCR rule applies to total debt, zero otherwise. ThinCap-partial is equal to one if the TCR applies only to related-party debt, zero otherwise. CitRate is the statutory corporate income tax rate. The variable tangibility is an industry-specific index that captures industry needs for external financing as in Rajan and Zingales (1998). Data are from ORBIS for 2005-14. *** $p<0.01,{ }^{* *} p<0.05,{ }^{*} p<0.1$. 


\section{REFERENCES}

Acemoglu, D., V. Carvalho, A. Ozdaglar, and A. Tahbaz-Salehi, 2012, "The Network Origins of Aggregate Fluctuations," Econometrica, Vol. 80, pp. 1977-2016.

Altman, E.I., 1968, "Financial Ratios, Discriminant Analysis and the Prediction of Corporate Bankruptcy," Journal of Finance, Vol. 23, pp. 589-609.

_- M. Iwanicz-Drozdowska, E. Laitinen, and A. Suvas, 2014, Distressed Firms and Bankruptcy Prediction in an International Context: A Review of Empirical Analysis of Altman's Z-score Model (New York: New York University Stern Business School).

Bernanke, B., and J.Y. Campbell, 1988, "Is There a Corporate Debt Crisis?" Brookings Papers on Economic Activity No. 1 (Washington, Brookings Institute).

Bianchi, J., 2011, "Overborrowing and Systemic Externalities in the Business Cycle," American Economic Review, Vol. 101, pp. 3400-26.

Blouin, J., H. Huizinga, L. Laeven, and N. Gaëtan, 2014, "Thin Capitalization Rules and Multinational Firm Capital Structure," IMF Working Paper No. 14/12 (Washington: International Monetary Fund).

Buettner, T., M. Overesch, U. Schreiber, and G. Wamser, 2012, "The Impact of Thin-Capitalization Rules on the Capital Structure of Multinational Firms," Journal of Public Economics, Vol. 96, pp. 930-38.

De Mooij, R., 2011, "The Tax Elasticity of Corporate Debt: A Synthesis of Size and Variations," IMF Working Paper No. 11/95 (Washington: International Monetary Fund).

Desai, M., and D. Dharmapala, 2015, "Interest Deductions in a Multijurisdictional World," National Tax Journal, Vol. 68, No. 3, pp. 653-80.

Feld, L. P., J. H. Heckemeyer, and M. Overesch, 2013, "Capital Structure Choice and Company Taxation-A Meta Study," Journal of Banking and Finance, Vol. 37, pp. 2850-66.

Friedman, B. M., 1986, "Increasing Indebtedness and Financial Stability in the United States," NBER Working Paper No. 2072 (Cambridge: National Bureau for Economic Research).

Giroud, X., and H. Mueller, "Firm Leverage and Unemployment during the Great Recession," Quarterly Journal of Economics (forthcoming).

Haufler, A., and M. Runkel, 2012, "Firms' Financial Choices and Thin Capitalization Rules under Corporate Tax Competition," European Economic Review, Vol. 56, 1087-103. 
Hebous, S., and M. Ruf, 2015, "Evaluating the Effects of ACE Systems on Multinational Debt Financing and Investment," CESifo Working Paper No. 5360 (Munich: CESifo).

Heckemeyer, J., and R. De Mooij, 2017, "Taxation and Corporate Debt: Are Banks any Different?" National Tax Journal, Vol. 70, No. 1.

Huizinga, H., L. Laeven, and G. Nicodeme, 2008, "Capital Structure and International Debt Shifting, Journal of Financial Economics, Vol. 88, pp. 80-118.

International Monetary Fund, 2016a, "Tax Policy, Leverage and Macroeconomic Stability," IMF Policy Paper FO/Dis/16/151 (Washington).

_ 2016b, Fiscal Monitor: Debt: Use it Wisely, October (Washington).

John, K., L. Litov, and B. Yeung, 2008, "Corporate Governance and Risk-taking," Journal of Finance, Vol. LXIII, pp. 1679-728.

Jordà, Ò, M. Schularick, and A. M. Taylor, 2013, "When Credit Bites Back," Journal of Money, Credit and Banking, Vol. 45, pp. 3-28.

Merlo, V, N. Riedel, and G. Wamser, 2015, The Impact of Thin Capitalization Rules on the Location of Multinational Firms' Foreign Affiliates, Mimeo.

Organisation for Economic Co-operation and Development (OECD), 2015, "Base Erosion and Profit Shifting, Action 4: Limiting Base Erosion Involving Interest Deductions and Other Financial Payments," Final Report (Paris).

Rajan, R., and L. Zingales, 1998, "Financial Dependence and Growth," American Economic Review, Vol. 88, pp. 559-86.

Sutherland, D., and P. Hoeller, 2012, "Debt and Macroeconomic Stability: An Overview of the Literature and Some Empirics," OECD Economics Department Working Papers No. 1006 (Paris: Organisation for Economic Co-operation and Development).

Weichenrieder, A, and H. Windischbauer, 2008, "Thin-Capitalization Rules and Company Responses-Experience from German Legislation," CESifo Working Paper No. 2456 (Munich: CESifo). 